\section{DiscoverSys \\ Published by DiscoverSys \\ Causes of unwanted pregnancy among adolescents in Bali Province: a qualitative study}

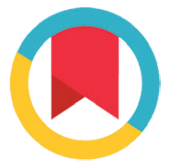

CrossMark
Kadek Anggie Wisandewi Mayun, ${ }^{1 *}$ Luh Seri Ani, ${ }^{1,2}$ Ni Luh Putu Suariyani ${ }^{1,3}$
Background and purpose: Teenage pregnancy is a major contributing factor of high maternal and infant mortality rates in Indonesia. Unwanted pregnancy among adolescents is increasing, therefore an understanding of its causes is essential. This study aims to explore causes of unwanted pregnancy among adolescents.

Methods: A qualitative study was conducted in Bali Province. Data were obtained through in-depth interviews with 10 adolescents aged between 12-21 years who experienced unwanted pregnancy. Data were collected between September and October 2016. Data were analysed thematically and presented using a narrative approach. Results: Our study revealed that determinants associated to unwanted pregnancy among adolescents included the lack of systematic education on sexual and reproductive health both at home and school, as well as the lack of self-efficacy of teenage girls to reject pre-marital sex with their partner. Our study found that this pre-marital sex was done as an expression of love, because of being forced by the partner, and due to stressful home environments.

Conclusions: The main causes of unwanted pregnancy among adolescents are the lack of sexual and reproductive health education and a weak self-efficacy of teenage girls to reject pre-marital sex demanded by their partner. Given the complexities of teenage pregnancy, overarching policy to facilitate an early comprehensive sexual and reproductive health education program at home, schools, and youth-friendly health facilities is warranted.
PPublic Health Postgraduate Program Udayana University, ${ }^{2}$ Department of Community and Preventive Medicine Faculty of Medicine Udayana University, ${ }^{3}$ School of Public Health Faculty of Medicine Udayana University

${ }^{*}$ Correspondence to: Kadek Anggie Wisandewi Mayun, Public Health Postgraduate Program Udayana University anggie.wisandewi@yahoo.com

Keywords: causes, adolescent, unwanted pregnancy, qualitative study Cite This Article: Mayun, K.A.W., Ani, L.S., Suariyani, N.L.P. 2017. Causes of unwanted pregnancy among adolescents in Bali Province: a qualitative study. Public Health and Preventive Medicine Archive 5(2): 90-94. D01:10.15562/phpma.v5i2.20

\section{INTRODUCTION}

Teenage pregnancy is a major contributing factor of high maternal and infant mortality rates in Indonesia. The National Statistical Bureau in 2012 stated that the national prevalence of teenage pregnancy (aged 15-19 years) was 48 per 1000 pregnancies. ${ }^{1}$ Relative to all pregnancies, the proportion of teenage pregnancy was $1.97 \%$ - which was slightly higher in rural areas $(2.71 \%)$ in comparison to urban counterparts $(1.28 \%){ }^{2}$ A study in nine big cities in Indonesia found that of a total of 37,000 unwanted pregnancies, as many as $27 \%$ were unmarried couples and $12.5 \%$ of these couples were junior/high school students or undergraduates. ${ }^{3}$

In Bali Province, Perkumpulan Keluarga Berencana Indonesia [The Indonesian Family Planning Association] or PKBI reported an increase number of unmarried couples aged between 10-24 years accessing pregnancy counselling services in the PKBI clinic. Teenage unwanted pregnancy cases increased from 236 cases (19.55\%) in 2013 to 308 cases $(24.16 \%)$ in 2014 , and went up to 320 cases $(25.49 \%)$ in 2015 . These cases were all unmarried adolescent couples aged between 10 and 24 years. ${ }^{4}$ The primary aim of this counselling was to terminate the pregnancy. The high rate of unwanted pregnancy among adolescents indicates the urgency to understand its complex underlying causes. This study aims to explore and to describe complex causes of unwanted pregnancy among adolescents.

\section{METHODS}

A qualitative study was conducted involving 10 pregnant teenage girls. These girls were purposively selected based on criteria of: age between 12 and 21 years with unwanted pregnancy who visited the ' $\mathrm{X}$ ' private clinic to terminate the pregnancy and agreed to be interviewed by the researcher. In-depth interviews were directly conducted by the researcher (first author) and were audio-recorded.

Data analysis started by transcribing the audio-recorded materials. Thematic analysis was employed to identify key themes emerged from the interviews. These themes were further analysed to generate patterns and to draw conclusion guided by the existing theoretical or literature. To ensure the rigor of our study, audit trial was employed to examine accuracy of information provided by informants, summary of in-depth interviews, key themes generated from data analysis, as well as key concepts found in literature review. ${ }^{5}$ This study protocol has been approved by the Human Research Ethics Committees, Faculty of Medicine Udayana University and Sanglah General Hospital Denpasar. Prior to interview, inform consent was obtained from each informant and their parent. Letter of 
permission was also obtained from the ' $\mathrm{X}$ ' private clinic prior to all data collection processes. Privacy and anonymity of all informants were also guaranteed by using only coded initials for each informant.

\section{RESULTS AND DISCUSSION}

Our study found that there were two main reasons identified which led teenagers into pre-marital sex and unwanted pregnancy: the lack of sexual and reproductive health education and a weak self-efficacy to reject pre-marital sex and unsafe sex.

\section{Lack of sexual and reproductive health education}

Information on reproductive health obtained from the family was only limited with regard to looking after yourself as a woman and a reminder to always 'alert' when engaging in a relationship with a man. These can be seen in the following quotes:

"...Yes, this is an advice to you ... Please respect yourself as you are a woman... We [father and mother] trust you... That's all what they told me..." (LA, 20 years)

"...My grandfather has remained me once... If you have a boyfriend, be alert... how far can you go with your boyfriend... I can talk openly to my grandfather... And I basically told him about my boyfriend, he insisted saying that I should be more careful and warned me about unwanted pregnancy... He also reassured me, if anything happened you should tell me ..." (SD, 17 years)

Outside the family, information were also received from school or teacher - but only about the impacts of pre-marital sex. In addition, they also obtained information from sporadic education programs from other institutions - mainly related to pregnancy and condom use. These can be observed in the following quotes.

“...Yeah, you know... 'don't do it, the pre-marital sex, because you might get pregnant' that's all what my lecturer ever said in class..." (MA, 21 years)

“...at school... there are promotion programs ... pregnancy happens when the 'egg' and the sperm met..." (KW, 19 years)

"...Yeah, it was explained when I was at school... Pregnancy can happen when the man ejaculated inside the woman... but if the man releases the sperm outside the woman, she won't get pregnant..." (WD, 18 years)
“...I know condom... it aims at preventing pregnancy... I was a member of KSPAN when I was at second year of my high school, but it only lasted for a week ... that's all..." (SD, 17 years)

Another source of information was their peers. It said by their peer that teenage pregnancy was a negative consequence of 'free lifestyle' as can be seen in the following quote:

"... Pregnancy is the negative effect of the free lifestyle ... I heard this when I spoke to my friend..." (PS, 19 years)

Source of information is related to the level of knowledge on reproductive health among teenagers. If their questions are not answered, they will seek information from other sources including internet, television, books, and their peers. These might lead adolescents to incorrect information on reproductive health. ${ }^{6,7}$ A comprehensive education on reproductive health will facilitate the transition from teenage life into an adult life - so that they may be responsible in their actions and can perfectly adapt to their new environment. ${ }^{8}$

Reproductive health education should be given when they enter a teenage life and should be tailored based on need, age, cognitive ability, and psychological development, both at formal school and informal institutions. This is essential to prevent unsafe sex among adolescents. ${ }^{6,9}$ Teenagers enter a transition period from teenager to an early adult when they are between 10 and 20 years old. ${ }^{10}$ In the context of an early reproductive health education program, information should no longer limited to gender and sex identification, but also should include moral aspect of reproductive health, for example providing comprehensive information on effects of 'free lifestyle' and pre-marital sex. ${ }^{6}$

Reproductive health education at home is essential for children because family is a place to lay foundation for norms and values. Parents should equip themselves with information and value systems as they are the main educator of their children at home. However, the majority of parents are not providing their children with enough information on reproductive health as they perceive it as promoting pre-marital sex. Therefore, parents interpret reproductive health education as taboo and is not a subject to talk about at home. ${ }^{6,11}$

Reproductive health should also no longer be treated as a 'discourse' but it can substantively be implemented in the education sectors. Schools as a formal education system play a major role to deliver reproductive health education program. Schools are also critical for psychological development of the children. Together with family as a primary 
education system for children, school is another learning centre for character building of children. ${ }^{12}$ School is an ideal institution to cultivate intellectual and moral values, unfortunately reproductive health has not been part of the national core curricula. Reproductive health is only 'an additional insertion' to be integrated with other core curricula when appropriate. ${ }^{13}$

\section{Lack of self-efficacy to reject pre-marital or unsafe sex}

The lack of self-efficacy of teenage girls to reject pre-marital sex and safe sex is another pathway of increasing unwanted pregnancy among adolescent. Teenagers assume that 'sex' is the way to prove love and to show commitment in the relationship. These can be seen in the following quotes:

"... Yeah because I love him... I want to be together for sure... He said that he is serious, that what he said to me..." (PS, 19 years)

“...Ya because I love him... He didn't force me... We talked then we just did it..." (WD, 18 years)

"... I like him... I don't know... I love him... I already with him for long time, and I don't mind doing it..." (AE, 14 years)

Teenage girls show their commitment by allowing pre-marital sex, even though their relationship was relatively short of less than one year as can be seen in the following quotes:

"...I never been in a relationship this long before... This is already long for me, four months... my previous relationships were short..." (SD, 17 years)

"...I already with him for five months... I don't see him very often, long distance relationship... Only when he works here then we meet..." (LS, 20 years)

Adolescent life is characterised by unstable physical growth and emotional development. ${ }^{14}$ They tend to be very sensitive and experience difficulty in controlling their emotional responses. ${ }^{15}$ The fluctuated physiological and emotional states or also called emotional arousal determines the self-efficacy among teenagers. When they emotionally loves their partner, they will obey their partner, including when they ask for a 'sex.'. ${ }^{16}$

In some instances, teenage girls were also forced by their partner to have sex. An empty house when all family members were out, the girl accepted it because she thinks no one will come to help. This can be seen in the following quote:

“... Yeah ... he forced me... It was at his place, nobody was really there... It's useless to scream..." (JL, 18 years)

This finding is consistent with a study conducted in Uganda related to risk factors of teenage pregnancy. They found that being forced by the partner is one reason of why teenage girls had sex and get pregnant. ${ }^{17}$ Other study also revealed that teenage girls were forced to have sex by their partner as a prove of their love. ${ }^{18}$ 'Being forced' results in emotional responses which influence the self-efficacy. When people are scared because of being forced, they tend to have a low self-efficacy to reject any action aiming at them. ${ }^{16}$

Furthermore, self-efficacy is also influenced by someone's position in social systems. ${ }^{16}$ Teenage girls in our study stated that after they had sex, they felt like they have been married for many years, like 'husband and wife' as can be seen in the following quote:

"...everything is with me now... 'mummy ... mummy...' Feel like we have been married for years..." (SD, 17 tahun)

Within the conventional family conception, the role of husband is dominant and perceived as the breadwinner, protector, and decision maker of the families. This status strategically positions men as superior to women where women is dependent towards men. ${ }^{19}$ This dependency places women as inferior to men and is more vulnerable for abuses. When a person considers to have a higher social value, a person tends to have a strong self-efficacy. In contrast, a lower social status will lower a person's self-efficacy. ${ }^{16}$

In addition, a functional family environment also contributed to self-efficacy. This study found that a stressful family environment influenced the decision made by teenage girls, including the pre-marital sex and pregnancy. This can be seen in the following quote:

"...It is because I am stress at home, I just want to be out from home, now because I am pregnant I have a reason to be out from my house..." (KW, 19 years)

Family is the first social environment and an essential part of character building of any individual, including teenager. ${ }^{14} \mathrm{~A}$ constant problem in the family might create uncomfortable environment 
for teenager which leads to stress and deviant behaviours such as pre-marital sex. When they cannot find peace at their home, they will actively seek for another place to find peace.

Furthermore, hostile relationship between parent and children can also lead to stressful family environment. Teenager needs a role model in the family as well as a 'protector' in the family. The absence of this role model inhibits teenager to open up to their parent. This also leads to confusion among teenagers about their role and position in the family. When they perceive that they have a lower status in the family, it will reduce the self-efficacy. ${ }^{16}$ Family especially parent is the primary environment which can facilitate teenagers to clarify their identity as a child in the family. A functional relationship between parent and teenagers is critical for their sexuality and reproductive health. The lack of role model in the family is the key factor why teenagers engage in deviant behaviours including pre-marital sex.

\section{Limitations and implications of the study}

Our study did not involve parents and related stakeholders as participants. Therefore, this study is unable to assess the level of knowledge among parents regarding reproductive health. Furthermore, this study is also unable to address issue on effects of parenting on pre-marital sex and unwanted pregnancy among adolescents.

Unwanted pregnancy among adolescents is a complex issue. We encourage policies to facilitate a comprehensive sexual and reproductive health education for teenagers, both at formal and non-formal education sectors as well as at youthfriendly health centres. Sexual and reproductive health education materials should be tailored based on age, so that it will be more effective in improving the knowledge of teenagers on reproductive health. This is essential because every phase of growth and development among teenager consists a different characteristic. A correct content and method of delivery will enable better understanding of sexual and reproductive health among adolescents. This lays a foundation for an understanding of the ethical and moral aspects of reproductive health thus preventing pre-marital sex act and eventually unwanted pregnancies.

Parents as the primary educator for children at home must equip themselves with information, intellectual capacity, and value systems. These qualities will determine the parenting and educating patterns performed by the parents. In addition, these qualities are also essential when they deliver information related to sexual and reproductive health to their children - with consistent and correct information. Parent plays a critical role in character building of teenagers, creating conducive environment for an open discussion between parent and children, and also providing sufficient control over the behaviours to improve teenagers' self-efficacy.

\section{CONCLUSION}

Unwanted pregnancy among adolescents is contributed by the lack of comprehensive reproductive health education both at home and schools, and the lack of self-efficacy of teenage girls to reject pre-marital and unsafe sex.

\section{ACKNOWLEDGEMENT}

We would like to thank our research participants and all stakeholders who had supported this study. I would also like to thank the head of the ' $\mathrm{X}$ ' Clinic who had facilitated this study.

\section{REFERENCES}

1. National Family Planning Coordination Board. Kepesertaan keluarga berencana dan faktor-faktor yang berhubungan dengan terjadinya unmet need KB pada pasangan usia subur di Kota Yogyakarta [Participation of family planning and factors associated to unmet need among reproductive age couple in Yogyakarta City]. Jakarta: National Family Planning Coordination Board; 2014.

2. Ministry of Health of Indonesia. Situasi kesehatan reproduksi remaja [Reproductive health situations among adolescents]. Jakarta: Ministry of Health of Indonesia; 2015.

3. Negare O. Situasi kesehatan reproduksi dan seksual di Bali [Sexual and reproductive health situations in Bali Province]. [cited 2016 January 19]. Available from: http:// www.ykai.net.

4. The Indonesian Family Planning Association Bali Branch. Laporan kunjungan konseling kehamilan pada tahun 2013 sampai 2015 di PKBI Bali [Report on pregnancy counselling visits year 2013 - 2015 in PKBI Bali]. Denpasar: The Indonesian Family Planning Association Bali Branch; 2016.

5. Bungin. Analisis data penelitian kualitatif [Qualitative data analysis]. Jakarta: Raja Grafindo Persada; 2012.

6. Rasyid M. Pendidikan seks, mengubah seks abnormal menuju seks yang lebih bermoral [Sex education, transforming abnormal sex into a moral sex]. Semarang: Rasail; 2013.

7. Wahyuni D. Tingkat pengetahuan anak sekolah usia 11-12 tahun tentang pubertas [Level of knowledge among school children aged 11 to 12 years on puberty]. Jakarta: University of Indonesia; 2002.

8. Surtiretna N. Remaja dan problema seks [Adoslecents and sexual problems]. Bandung: Remaja Rosdakarya; 2006.

9. Gunarsa S. \& GS. Psikologi Praktis: anak, remaja dan keluarga [Practical psychology: child, teenager, and family]. Jakarta: BDK Gunung Mulia; 1991.

10. Sobur. Psikologi umum [General psychology]. Bandung: Pustaka Setia; 2011.

11. Verawati. Pendidikan seks pada anak, pentingkah? [Sex education among children, is it important?]. [cited 2017 July 2] Available from: http://sulbar.bkkbn.go.id/Lists/ Artikel/DispForm.aspx?ID=130 12.

12. Hamali. Psikologi belajar mengajar [Psychology of teaching]. Bandung: Sinar Baru Algesindo; 2009. 
13. Soetjiningsih. Tumbuh kembang remaja dan permasalahannya [Adolescent development and its problems]. Jakarta: Sagung Seto; 2004.

14. Sarwono. Psikologi remaja [Adolescents psychology]. Jakarta: Rajawali Press; 2010.

15. Bandura. Self-Efficacy Theory. Available from: https:// samples.jbpub.com/9781449689742/Chapter2.pdf (1997).

16. Kwokwijuka BG. Risk factors of adolescent pregnancy in Kabale District-Uganda [dissertation]. Uganda: Makerere University; 2009.

17. Richter MS, Mlambo GT. Perceptions of rural teenagers on teenage pregnancy. Heal SA Gesondheid; 10. Epub ahead of prin; 2005.
18. Aisyah N. Relasi Gender dalam institusi keluarga (pandangan teori sosial dan feminis) [Gender relations inside the family - social and feminism theoretical perspectives]. Jurnal Kajian Gender. 2013; 5(2): 203-224.

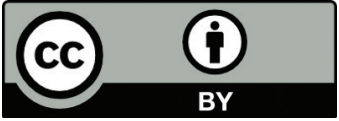

This work is licensed under a Creative Commons Attribution 